\title{
Promoting social inclusion counting with everyone: Learning Communities and INCLUD-ED
}

\author{
Suzanne Gatt ${ }^{\mathrm{a}}$, Mikko Ojala ${ }^{\mathrm{b}}$ and Marta Soler ${ }^{\mathrm{c} *}$ \\ ${ }^{a}$ Department of Primary Education, University of Malta, Msida, Malta; \\ ${ }^{b}$ Department of Applied Sciences of Education, University of Helsinki, Helsinki, \\ Finland; 'Department of Sociological Theory, University of Barcelona, \\ Barcelona, Spain
}

\begin{abstract}
The scientific community has provided a wide range of evidence that family and community involvement in schools benefits not only students' learning but also their surrounding community. The INCLUD-ED project has conducted case studies of successful schools around Europe that have strong community participation. Some of them are engaged in the Learning Communities project, an international project of educational and social transformation aimed at overcoming school failure. Through these case studies, INCLUD-ED has gone beyond the state of the art in the field and has provided a classification of types of family and community participation and identified forms of involvement that improve students' academic achievement. This article presents the benefits of those forms of participation and focuses on some forms of community involvement in the Learning Communities that have been found to improve students' school learning and other education-related aspects, such as living together.
\end{abstract}

Keywords: Learning Communities; community involvement; inclusion; school and community partnerships; school success

\section{Introduction: community involvement and school success}

Promoting educational success is one of the main priorities for Europe to combat social exclusion. The perception of difficult times, however, commonly arises in the educational discourse as a result of globalisation, migration flows and increasing diversity in the classroom. The feeling of not being able to cope with the increasingly diverse needs of students makes educators often engage in blaming the low achieving students and their families for their own failure. This is usually the result of a perspective widely used in surveys that establish a relationship between levels of education of families, or their cultural capital, and school performance, which might end in a deterministic or incorrect interpretation of everyday practices in many schools. Current research, however, is providing evidence about the relationship between family and community

*Corresponding author. Email: Marta.Soler@ub.edu

ISSN 0962-0214 print/ISSN 1747-5066 online

(1) 2011 Taylor \& Francis

DOI: $10.1080 / 09620214.2011 .543851$

http://www, informaworld.com 
involvement and school success, opposing traditional analyses linked to cultural capital and highlighting instead the different community-school partnership arrangements. There are schools in Europe in which teachers, families and communities build common collaborative projects to help their children excel. These schools include these families as a useful resource to transform the learning opportunities these students have, for instance, in a low-socioeconomic status (SES) neighbourhood school. Moreover, as society becomes more complex and as more professional knowledge is accrued about child development, learning and social integration, educating children becomes both harder and a more challenging task for educators to address by themselves. Families and communities can contribute the intimate knowledge of students that professionals sometimes struggle to achieve. A school graduate or a sibling would be much closer to a sixth grader than would her teacher.

The series of challenges facing educational systems across Europe, therefore, can only be overcome through a joint and coordinated effort by all those involved. Education is a shared responsibility of the whole community, working with different types of professionals, teachers and educators. The international scientific community has already provided a wealth of research showing the relationship between community involvement and educational success. Drawing on this research, this article first provides an overview of the literature on family and community participation and school success. Second, it provides an example of how this community involvement takes place in a particular ongoing project: the Learning Communities. Drawing from what we already know from the literature, the INCLUD-ED ${ }^{1}$ project represents an attempt to move beyond the state of the art in the field. It has provided a classification of types of family and community involvement and has indicated four forms through which those types take place in schools that are successful: participation in decision making processes; participation in curriculum development and evaluation; family education; and participation in learning spaces. We focus on the benefits of those forms of family and community participation and how those forms occur in schools engaged in the Learning Communities project. The article ends with some reflections on how these research findings can inform educational practices in schools across Europe.

\section{What does the literature say about the role communities play in promoting social inclusion?}

The term community carries multiple meanings. In the twentieth century, the German sociologist Ferdinand Tönnies (1957) distinguished between Gesellschaft, referring to an association between people based on its members' pursuit of self-interest, and Gemeinschaft, where the association is based on shared purposes, personal loyalties and sentiments. On this basis, some authors have discussed community education as the educational actions needed to develop a positive sense of community (Mintzey and LeTarte 1994) 
or the actions undertaken to promote a sense of belonging, to support cohesion through commitment and to embrace diversity (Watkins 2007). Other authors have discussed the participation of community members in institutional decision making (Fung and Wright 2003) or in educational institutions (Freire 1970) to improve democracy and increase educational opportunities.

In relation to the second approach, there is research that has proved the benefits of community involvement. The Harvard Family Research Project includes different studies about these benefits for children's academic achievement. For instance, in the Home-School Study of Language and Literacy Development, Snow and Tabors (2002) found that the support for literacy both at home and in school was a much more powerful predictor of early literacy abilities than families SES or cultural background. This data demonstrate that the work conducted with families and communities to promote literacy practices or develop cultural activities will have a direct impact on their children's achievement. Other scholars have stated that, in fact, family engagement and participation in the children's education helps them to succeed from 'cradle to career' (Westmoreland et al. 2009). Parents have always been interested in their children's education, but they have traditionally had fewer opportunities to be involved in the schooling process, depending on the orientation of school policies. Globally, this is partly the outcome of a culture of education that leaves little room for families and it is difficult to decentralise the power that is very often monopolised by education professionals. This is the reason why, despite the latest policies and developments, schools are still places where parents and community members step in just occasionally and in a limited manner. Moreover, social class, income and status have a significant effect on generating dynamics of discrimination, affecting certain families both in the way their views are perceived within some school contexts and in the way their levels of empowerment in practices of parental and community involvement are more or less promoted (Hill and Taylor 2004).

As the educational reality becomes more and more complex, partnerships between schools and communities are gaining relevance in the literature and the notion of parental involvement is adopting a wider perspective. After years of research in the area, Epstein and Sheldon (2006) advocate school, family and community partnerships as a better way of placing school actions within the community, as they recognise that parents, educators and other community members share responsibility for students' learning and development. In addition, some researchers seek to answer the question of whether schools are actually practising parental involvement (Foot et al. 2002; Tett 2002) and whether such involvement has an impact on students' achievement and general well-being at school (Edwards and Warin 1999; Senechal and LeFevre 2002).

Another body of research has explored whether one of the benefits of promoting community involvement is civil society development and growth of grassroots democracy. This perspective includes a deeper level of analysis: 
whether contemporary forms of parental involvement are empowering parents democratically and politically; whether they are given an active role in decisionmaking over their children's education. In this regard, community and parental involvement in schools is strongly related to critical education and democratic schools (Apple and Beane 2007). Participation in the learning process and decision-making power is central (Marcon 1999; Serico 1998). Nonetheless, the concept of school-community relationships can be fruitful in providing an added understanding of community 'empowerment' as a force in school improvement, as well as developing further knowledge about co-productive 'partnering' between the school and community (Crowson 2001).

Other researchers have focused on whether or not community involvement and Learning Communities in schools promote children's academic improvement. Improvement was noted in literacy (Faires, Nichols, and Rickelmann 2000; Jordon, Snow, and Porche 2000) in the early years of schooling. When low-income parents improve their reading skills, they have more opportunities to overcome traditional barriers they find in the school context and then to promote changes in themselves so they can better fit into the school culture (Paratore et al. 1999). This is why governments need to ensure equity in the distribution of literacy programmes (Ponzetti and Dulin 1997). The use of volunteers was also found to help primary-level students develop their reading skills (Fitzgerald 2001) and community involvement programmes helped older primary-level students make progress in reading (Epstein 1983; Epstein and Sheldon 2006).

This kind of involvement has also had positive effects on children, encouraging them to continue their academic studies and achieve better grades. According to one study of the Harvard Family Research Project (2007), family participation that continued for at least three years encouraged children to continue their studies for longer. For example, students' scores in mathematics improved when they experienced community involvement at school. This was related to children's self-concept as learners in mathematics reflecting their parents' views of them and their capabilities in mathematics (Frome and Eccles 1998). In the case of science, parents' attitude toward the subject was found to play an important role in the children's interest and achievement in the subject (George and Kaplan 1998).

Other studies have identified effects on non-academic aspects. Sanders and Sheldon (2009) refer to a research project that shows the impact of community involvement on students: reduced absenteeism, better behaviour and improved attitudes and adjustment. It has also been argued that for school and curricular reform to take place and be sustained there needs to be community involvement (Arriaza 2004). This is because family literacy programmes help parents to help their own children and also enable their voices to be heard in the learning and development of their own children (Tett 2002). The case studies conducted by INCLUD-ED (2006-2011) indicate that when volunteers participate in the school, it promotes a feeling of belonging among the families. This 
happens because the walls of the school are no more limiting, but in fact access is available for all who want to participate. In the Learning Communities Project volunteers participating in joint learning activities can also enrich the work of the teachers. We found a connection between the participation of volunteers in school learning spaces and improved academic achievement, but also with a growing spirit of living together among all members from the school community.

\section{The Learning Communities project}

The Learning Communities project consists of the transformation of schools and their socio-cultural environment in order to achieve academic success for all students (Díez and Flecha 2010). The schools that are implementing the Learning Communities project are overcoming school failure and improving coexistence (CREA 2008, 2009). In order to achieve this they are implementing successful educational actions through the participation of the community in all of the areas of the school, from management bodies to classrooms. These are schools with a long trajectory of dedication to social transformation from education, opening up the doors to social inclusion for many children.

The Learning Communities project started in Spain in 1978, in La Verneda-Sant Martí, a school for adults in a working-class neighbourhood in Barcelona. The project started as a joint process of transformation that involved the school and the neighbourhood. Since then, La Verneda's project has impacted not only the learning of the participants but has also generated social and cultural transformations (Sánchez 1999). The success of this experience was such that it became a benchmark for efforts to extend this model to other schools. Thus, in 1995-1996, in Bilbao, the Learning Communities project started at the level of compulsory education. After the first elementary school, and in the light of the improvements obtained there, other schools in the Basque Country began to follow the Learning Communities model; soon schools in other regions of Spain also took up the this model. Currently, about 80 schools all around Spain, at different levels, including pre-primary, primary, secondary and adult education, have been transformed into Learning Communities. Furthermore, three pre-primary/primary schools in Brazil are working as Learning Communities, as are two in Chile.

The Learning Communities project is based on the theory of dialogic learning (Flecha 2000), which is based on the premise that learning depends on the interactions and dialogue that students experience not only with teachers but also with other students, with their families and with other people in their neighbourhoods and communities. Dialogic learning is rooted in the most important social science theories, such as the theory of dialogic action (Freire 1997) and the theory of communicative action (Habermas 1984). According to Habermas (1984), humans are social agents capable of language and action and according to Freire (1977) they have the capacity, and the need, to transform their lives 
and shape the context in which they find themselves. Also, dialogic learning is grounded in Vygostky's (1978) socio-cultural psychology, so the Learning Communities take into account the need to transform the learning context in order to enhance students' learning.

Given that access to quality education is increasingly important in modern society (Ojala 2004), Learning Communities have the ultimate objective of contributing to every child's inclusion in the information age. For this to happen, the school engages in a series of transformations that are grounded in research and that have the common trait of being community-based. The close collaboration between families, community and school is a key factor in the Learning Communities project, due to the fact that in the information society learning depends more and more on the correlation of the interactions that children have with everyone in their environment than only with teachers in classrooms (Aubert et al. 2008). Meeting this need also implies opening the school to the participation of diverse people and, in this sense, the Learning Communities project entails a profound democratisation of the school, something that is essential to achieve excellence and equity in any educational institution.

Family and community involvement in Learning Communities goes beyond the forms of participation that have traditionally limited family participation in schools to attend meetings and conferences and receive information about the school's projects. In contrast, in Learning Communities, family and community members are central in school decision-making, from the moment when the school decides whether it wants to be transformed into a Learning Community until the design of the activities offered during and after school time.

The transformation process begins in the stage called 'raising awareness'. This consists of research-based training sessions in which all the participants reflect on how today's society is formulated. In this intensive course the theoretical and research basis of the Learning Communities project are shared and the series of successful actions that compose the project are explained and discussed. In this stage of the process, schools are already encouraged to involve as many people related to the school as possible, so that more community members and other social agents get to know the scientific reasons for the transformation of the school and can envision the results of this process of reform. Once all the teachers, families and community members understand what the Learning Communities imply, and have discussed it in relation to their own situation in the school, then they decide whether or not they are willing to become a Learning Community. The project requires the agreement of most of the teaching staff and the students' families and the involvement of community agents and organisations. Once the whole community decides to become a Learning Community, they prepare to 'dream' about the type of school that they would like to have. All the different agents from the community (teachers, families, other community members, students and community representatives) express 
their dreams about what they would like the school to become. The overarching dream is an Information Society for everyone and wishing for other people's children what we want for our own. Then the different groups share their dreams and agree on a common and shared vision of the school. Later, and based on those dreams, they prioritise the actions required to transform the school. In the next stage, a new participation structure (based on various mixed committees and a management committee) is created for everyone to be able to participate in the decision-making processes that will turn dreams into practice.

\section{The way forward in community involvement: the INCLUD-ED project}

Part of the research carried out for the INCLUD-ED project, mainly in its longitudinal case studies (project 6), focuses on community involvement in schools and its relation to educational success. First, the analysis of theories, systems and educational results in Europe led to the development of a classification of five types of family and community participation: informative, consultative, decisive, evaluative and educative (INCLUD-ED Consortium 2009). It was also found that decisive, evaluative and educative forms of family and community participation are more likely to have a positive impact on student learning. The decisive type of participation implies that community members participate in decision-making processes. In the evaluative type of participation, family and community members participate in the evaluation of both students' learning processes and the school's progress. In the educative type, family and community members participate in family education activities and/or support students' learning in the school context.

This classification of five types of family and community involvement was used in NCLUD-ED for the study of family and community participation in educational projects that are integrating social and educational interventions that help to reduce inequalities and marginalisation and foster social inclusion and empowerment. Concretely, the forms through which the different types of family and community involvement take place in successful schools were explored in a four-year longitudinal case study of six schools in five different EU member states: Finland, Lithuania, Malta, Spain and the UK. The two schools from Spain follow the Learning Communities model. These case studies have provided new knowledge about the presence and impact of the aforementioned types of participation in schools serving students and families from low-SES and minority backgrounds that enjoy strong community involvement and have demonstrated a contribution to school success (as reflected by students progress in academic attainment) in relation to their context.

Concretely, in the second round of these case studies it was found that in the successful schools studied there were four main forms of family and community participation: participation in school-based decision-making processes, participation in curriculum development and evaluation issues, participation in family and community education and participation in classrooms and in other 
learning spaces. In the third round, the research team focused on identifying the links between the different forms of community involvement and school success. Data from this third round has shown that the forms of family and community involvement in the schools studied enhance students' learning in different ways and improve the living together in classrooms and in other learning spaces of the school.

In relation to the two schools engaged in the Learning Communities project, the results of the case studies have indicated that among the three types of community participation that are more likely to enhance students' learning, educative and decisive forms of community participation are greatly present in these schools. In what follows, more detail is provided on the findings regarding the benefits of different forms of educative and decisive participation that have been found in the successful schools studied. Finally, the specific forms that take place in the schools following the Learning Communities model are discussed.

\section{Participation in decision-making processes}

Community participation in decision-making aspects of the school has been demonstrated to have a positive impact on various aspects, for example, children whose parents were involved demonstrated lower rates of absenteeism. Being involved in decision-making processes also fostered a feeling of belonging and respect for the structures as well as the school, even at the curricular level, as families had some influence over the type of academic activities carried out. This allowed making the curriculum more significant and thus more meaningful to the children - and they performed better academically. In addition, by participating the families came closer together and interacted more and, in turn, this promoted better relationships between the different groups of children, among the families themselves and, of course, between the school and the families.

In the Learning Community schools, families and community members participate in the school management and decision-making processes from the very beginning of the project, as it happens in the 'dream phase'. At that very initial stage, general assemblies are organised or different participation avenues developed for everybody to have a say about the school of their dreams. Each centre organises it in a different way, but the central idea consists in dreaming of the school they wish. This creates a sense of belonging to the school that was expressed by a Moroccan father who stood up and thanked the school for organising his dream assembly at $10 \mathrm{o}^{\prime}$ clock at night, as it was the first time he was able to participate in a school activity. Amazingly all the dreams are very well connected and very often coincide. Once the dream has been articulated by students of all grades, families, teachers, community members and so on, then it is time to get organised in order for everyone to work for making all these dreams come through. 
Taking the community dream as the shared horizon, the Learning Community is later organised through mixed committees. These are democratic working groups, which include teachers, students, family members and other representatives from the community. Each mixed committee is focused on specific themes such as academics, volunteering, school infrastructure, community outreach and so on. These committees address those issues that have come up in the dream phase and, in this sense, different committees are created depending on the dreams that have come up in each school. In these committees, all of the members can participate and contribute freely, based on egalitarian dialogue, independently of their position in the school. Agreements are reached by the force of the arguments and not from the force derived of the position occupied by the person that formulated the idea. A teacher's opinion does not have more weight than a family member or student one. Opinions are valued according to the force of the arguments underlying them. It is in this way that the Learning Communities manage to generate a re-enchantment with participation, which includes people's right to decide on the issues that directly affect their children. All the families can decide, without exception, including those who traditionally have been mostly excluded. For instance, in one of these mixed committees, illiterate Romani mothers are the ones insisting in the importance for their children to learn English or Computing, as they want them to be judges and engineers. As members of the mixed committee dedicated to enhance students' learning, these Romani mothers co-design the ways to make their dream happen. These examples show that given the chance, all families have a lot to say about their children's education and about ways to improve it.

\section{Family education}

The results of the case studies have indicated that participation of family members in family education enhances students' academic achievement. It encourages children to engage more positively in learning activities, leading to better academic achievement. It helps families transmit a positive view of learning and empowers relatives to feel that they can help their children with their homework. This favours children and their relatives sharing school knowledge and working together at home, thus increasing academic interactions. In a more indirect way, evidence showed that family education enables family members to revisit academic aspirations for their children and enables participating adults to become role models for the students. Moreover, family education facilitates better and more regular relationships between families and the educational staff, which improves children's behaviour. It also fosters a sense of ownership within the school for both families and children.

In the Learning Communities project, family education is a priority. Family members participate in educative activities that meet their needs. Actually, most of the family education courses result from the relatives' own education demands. For example, immigrant parents participate in second language 
classes and in ICT courses. Among the different activities of family education, ones that have been shown to have great success of participation and potential to influence children's learning are the dialogic literary gatherings (Flecha 2000). In the dialogic literary gatherings, adults who had never read a book before or are in the initial stages of the literacy process read and discuss classic books. Through this activity, the participants engage in new reading practices and cultural roles, which influence their children's school learning.

In one of the elementary schools studied, during the 2009-2010 school year, between 8 and 10 Muslim immigrant mothers met weekly to read $L a$ Casa de Bernarda Alba, a classic novel by García Lorca. The participant women explained that the knowledge and experience they gain in the dialogic literary gathering allow them to communicate with other autochthonous people, to help their children with their homework and to be able to go to the doctor by themselves, among other everyday activities. This participation not only transforms the educational environment in the school and their homes, but also helps to improve their lives.

\section{Participation in classrooms and other learning spaces}

The results of the case studies have shown also that the participation of families and other adults in classrooms and other learning spaces in the school greatly influences students' learning and school success. When family and community members participate in the learning spaces of the school, this increases the human resources available in classrooms, the library, computer rooms or the school radio station, multiplies and diversifies learning interactions and therefore fosters children's school learning.

The participation of family and community members in classrooms and other learning spaces is very common in the Learning Communities. In the classroom, this occurs through the Interactive Groups. In this inclusive form of classroom organisation children are placed into small heterogeneous ability groups and an adult monitors their work (see Mircea Alexiu and Sorde this issue). The classroom teacher manages the whole dynamic. Usually, the volunteers represent the diversity amongst the students in the school, contributing to connect what happens in the classroom with life outside the school. The research results show that when family members from diverse backgrounds participate in Interactive Groups within the classroom, children put more effort into their work and their motivation to learn increases (see also Christou and Puigvert this issue). Children also pay more attention to the teaching offered by both adults and peers and the collaboration that takes place among students promotes meaningful dialogic learning and raises solidarity.

In the Learning Communities, family and community members also participate in the other spaces of the school supporting children's learning, such as in the tutored library and the tutored computer rooms. In the tutored library, adults from the community and beyond manage the reading and 
learning activities in the school library, help children to read, support students with their homework and participate along with children in various reading activities, such as the dialogic literary gatherings. This system promotes a closer link with family life, resulting in more and better educational interactions and thus better academic performance. In addition, this form of family and community involvement often takes place after instructional time, which extends the learning time, something that has been identified as an inclusive action that fosters students' learning (INCLUD-ED Consortium 2009).

\section{Final remarks}

Family and community involvement in the schools open up new possibilities to promote educational success and therefore social inclusion in Europe. The research conducted within the frame of the INCLUD-ED project indicates that with the participation of everyone it is possible to better face the challenges found at the frontline of schools today. The case studies of successful schools in Europe engaged in learning projects with strong community involvement show that successful learning requires a strong support system provided by the educational professionals, but also from the children's immediate family as well as the community within which they live.

Reviewing the literature on systems, theories and practices in Europe has led to a classification of types of family and community involvement in schools: informative, consultative, decisive, evaluative and educative. Later, through the study of successful educational projects with strong community involvement, INCLUD-ED has found that in these schools forms of participation associated with the decisive, evaluative and educative types are common. Concretely, successful schools with strong community involvement around Europe have developed venues and structures for family and community involvement in decision making processes, in curriculum development and in evaluation processes; they also offer family education and involve parents and other community members in classrooms and in other learning spaces of the school. Through this kind of participation, an environment develops where high expectations towards students' potential become a shared value among parents, community members and educational professionals.

Two schools that follow the Learning Communities model are among the case studies of schools engaged in community-based educational projects that are successful. The long standing experience found in the Learning Communities project represents an example of how the space for school improvement that represents community involvement is already being used around the world. Nearly a hundred of these Learning Communities are showing that schools, families and communities can work together towards promoting educational success and social cohesion for all. This example is already serving as a model taken by several regional governments in order to enhance educational success in their territories. 
The results of the research in the two schools engaged in the Learning Communities model indicate that the Learning Communities greatly emphasise the decisive and educative types of family and community involvement. In these schools, there are specific forms to ensure participation in decision making processes, such as the 'dream phase' and the 'mixed committees'. There is also strong dedication to foster family education in the school and to involve families and other community members in learning spaces. With regard to family education, the dialogic literary gatherings constitute a successful way of engaging the community in education activities. This cultural activity has a very positive influence in the interactions between family members and children and contributes to dismantle cultural stereotypes and break down elitism. As for the involvement in learning spaces, the participation of parents and other members of the community in Interactive Groups in the classrooms has been evidenced as a very successful inclusive way of grouping students that enhances all children's learning. Due to the success of the transformative actions that are carried out in the Learning Communities, in 2008 the Basque Country government developed a plan to extend this work to its entire school system. ${ }^{2}$

As presented, the scientific analysis conducted through INCLUD-ED serves to advance the existing knowledge on community involvement and its effects on the students, the school and the surrounding environment. Particularly, it serves to analyse in depth the processes of transformation undertaken at these schools and their effects on students' learning and social cohesion. However, it does not stop here. The project is also aimed at identifying those universal elements that can be transposed to other contexts and to inform effective educational and social policies. In this regard, even though research clearly points out the multiple advantages and benefits of community involvement, much still needs to be done to open up the schools. INCLUD-ED is committed to shedding some light on how successful schools have opened up their doors to the community in order to promote community involvement not only at the practice level but also in identifying ways to endorse it as policy. The results obtained by the Learning Communities make these schools a model for how to promote social inclusion involving everyone.

\section{Notes}

1. The reports with the results of these longitudinal case studies are available at the INCLUD-ED website http://www.ub.edu/includ-ed/index.htm

2. More information available at $h t t p: / / w w w . u b . e d u / i n c l u d-e d / n e w s C B C . h t m l$

\section{Notes on contributors}

Suzanne Gatt is a Senior Lecturer at the University of Malta and has recently been involved in researching community involvement in primary schools as part of the FP7 INCLUD-ED project as well as young children's ideas about animals and plants. She is a teacher educator and a science educator. 
Mikko Ojala is a professor in pre-school and early elementary education at the University of Helsinki, Finland. Serving as a national leader for the IEA Preprimary project he has published several cross-cultural studies. He has published several textbooks and served as international expert for EU, OECD, OMEP and Swedish Research Council. Since 2007 he has worked as national project leader for the INCLUD-ED project.

Marta Soler, a Harvard Doctorate holder, is a Senior Lecturer in Sociology in the University of Barcelona, and director of CREA (Centre of Research in Theories and Practices that Overcome Inequalities). She has participated in RTD projects from the EU FP5 and FP6, serving as the Knowledge Management Committee coordinator for the INCLUD-ED project. She has published with John Searle, among others.

\section{References}

Apple, M.W., and J.A. Beane. 2007. Democratic schools: Lessons in powerful education. Portsmouth, NH: Heinemann.

Arriaza, G. 2004. Making changes that stay made: School reform and community involvement. High School Journal 37, no. 4: 10-24.

Aubert, A., A. Flecha, C. García, R. Flecha, and S. Racionero. 2008. Aprendizajedialógico en la sociedad de la información [Dialogic learning in information society]. Barcelona: Hipatia Editorial.

Centre of Research in Theories and Practices that Overcome Inequalities (CREA). 2008. Working papers: Case studies of local projects in Europe. 2nd Round Spain. INCLUD-ED Project. Strategies for inclusion and social cohesion in Europe from education, 2006-2011. 6th Framework Programme. Citizens and Governance in a Knowledge-based Society. CIT4-CT-2006-028603. DirectorateGeneral for Research, European Commission.

Centre of Research on Theories and Practices that Overcome Inequalities (CREA). 2009. Case analysis of local projects working towards social cohesion - Spain. Report Project 6, 3rd Round. INCLUD-ED Project. Strategies for inclusion and social cohesion in Europe from education, 2006-2011. 6th Framework Programme. Citizens and Governance in a Knowledge-based Society. CIT4-CT2006-028603. Directorate-General for Research, European Commission.

Crowson, R. 2001. Community development and school reform: An overview. In Community development and school reform, ed. R. Crowson, 1-18. Oxford: Elsevier.

Díez, J., and R. Flecha, ed. 2010. Comunidades de aprendizaje: Special issue [Learning Communities: Special issue]. Revista Interuniversitaria de Formación del Profesorado 67, no. 24: 19-30.

Edwards, A., and J. Warin. 1999. Parental involvement in raising the achievement of primary school pupils: Why bother? Oxford Review of Education 25, no. 3: 325-41.

Epstein, J.L. 1983. Longitudinal effects of family-school-person interactions on studentoutcomes. In Research in sociology of education and socialization, ed. A. Kerckhoff, 10I-28. Greenwich, CT: JAI.

Epstein, J.L., and S.B. Sheldon. 2006. Moving forward: Ideas for research on school, family and community partnerships. In Handbook for research in education: Engaging ideas and enriching inquiry, ed. C.F. Conrad and R. Serlin, 117-38. Thousand Oaks, CA: Sage.

Faires, J., W.B. Nichols, and R.J. Rickelmann. 2000. Effects of parental involvement in developing competent readers: First grade. Reading Psychology 21: 195-215. 
Fitzgerald, J. 2001. Can minimally trained college student volunteers help young at-risk students to read better? Reading Research Quarterly 36: 28-46.

Flecha, R. 2000. Sharing words: Theory and practice of dialogic learning. Lanham, MD: Rowman \& Littlefield.

Foot, H., C. Howe, B. Cheyne, M. Terras, and C. Rattray. 2002. Parental participation and partnership in pre-school provision. International Journal of Early Years Education 10, no. 1: 5-19.

Freire, P. 1970. Pedagogy of the oppressed. London: Continuum International.

Freire, P. 1997. Pedagogy of the heart. New York: Continuum International.

Freire, P. 1977. Pedagogy in process: The letters to Guinea-Bissau. New York: Seabury Press.

Frome, P.M., and J.S. Eccles. 1998. Parents' influence on children's achievementrelated perceptions. Journal of Personality and Social Psychology 74, no. 2: 435-52.

Fung, A., and E. Wright. 2003. Deepening democracy: Institutional innovations in empowered participatory governance. London: Verso.

George, R., and D. Kaplan. 1998. A structural model of parent and teacher influences on the science attitudes of eighth graders: Evidence from NELS:88. Science Education 82: 93-109.

Habermas, J. 1984. The theory of communicative action. Volume I: Reason and therationalisation of society. Boston, MA: Beacon.

Havard Family Research Project. 2007. Family involvement makes a difference: Evidence that family involvement promotes school success for every child of every age. No 2 Winter 2006/2007. Cambridge, MA: Harvard Family Research Project.

Hill, N.E., and L.C.P. Taylor. 2004. Parental school involvement and children's academic achievement: Pragmatics and issues. Current Directions in Psychological Science 13, no. 4: 161-4.

INCLUD-ED Consortium. 2009. Actions for success in schools in Europe. Brussels: European Commission.

INCLUD-ED Project. Strategies for inclusion and social cohesion in Europe from education. 2006-2011. 6th Framework Programme. Citizens and Governance in a Knowledge-based Society. CIT4-CT-2006-028603. Directorate-General for Research, European Commission.

Jordon, G.E., C.E. Snow, and M.V. Porche. 2000. Project EASR: The effect of a family literacy project on kindergarten students' early literacy skills. Reading Research Quarterly 35: 524-46.

Marcon, R.A. 1999. Positive relationships between parent-school involvement and public school inner-city preschoolers' development and academic performance. School Psychology Review 28, no. 3: 395-412.

Mintzey J.D., and C.E. Le Tarte. 1994. Reforming public schools through community education. Dubuque, IA: Kendall/Hunt.

Ojala, M. 2004. Looking for quality in early childhood education. In M. Lundqvist \& C. Öhberg (eds.), Det synliga barnet: Praktiska och teoretiska perspective pà pedagogiken. Rapport frän Pedagogiska fakulteten vid Abo Akademi [The visible child: Practical and theoretical perspective on education. Report from the Educational Faculty at the Turku Academy], 131-40. Vasa: Abo Akademi.

Paratore, J.R., A. Hindin, B. Krol-Sinclair, and P. Duran. 1999. Discourse between teachers and Latino parents during conferences based on home literacy portfolios. Education and Urban Society 32: 58-82.

Ponzetti, J.J., and W. Dullin. 1997. Parent education in Washington State Even Family Literacy Programs. Early Childhood Education Journal 25, no. 1: 23-9. 
Sánchez, M. 1999. La Verneda Sant Martí: A school where people dare to dream. Harvard Educational Review 69, no. 3: 320-35.

Sanders, M., and S. Sheldon. 2009. Principal matter: A guide to school, family and community partnerships. Thousand Oaks, CA: Corwin Press.

Senechal, M., and J. LeFevre. 2002. Parental involvement in the development of children's reading skills: A five-year longitudinal study. Child Development 73, no. 2: $445-60$.

Serico, J.G. 1998. School advisory councils: A case study of parent participation indecision-making. Ann Harbor, MI: UMI.

Snow, C., and P. Tabors. 2002. Young bilingual children and early literacy development. In Handbook of early literacy research, ed. S. Neuman and D. Dickinson, 159-78. New York: Guilford Press.

Tett, L. 2002. Community education, lifelong learning and social inclusion. Edinburgh: Dunedin Academic Press.

Tönnies, F. 1957. Community and society. East Lansing: Michigan State University Press.

Vygotsky, L.S. 1978. Mind in society: Development of higher psychological processes. Cambridge, MA: Harvard University Press.

Watkins, C. 2007. Classrooms as Learning Communities: What's in it for schools? NewYork: Routledge.

Westmoreland, H., M. Heidi, M. Rosenberg, E. Lopez, and H. Weiss. 2009. Seeing is believing: Promising practices for how school districts promote family engagement. Issue Brief, July. Boston, MA: Harvard Family Research Project. 